Article

\title{
Profiling Bacterial Diversity and Potential Pathogens in Wastewater Treatment Plants Using High-Throughput Sequencing Analysis
}

\author{
Cecilia Oluseyi Osunmakinde ${ }^{1}\left(\mathbb{D}\right.$, Ramganesh Selvarajan $^{2}{ }^{\circledR}$, Bhekie B. Mamba ${ }^{1}$ and \\ Titus A.M. Msagati ${ }^{1, * \mathbb{D}}$ \\ 1 Nanotechnology and Water Sustainability Research Unit, College of Science Engineering and Technology, \\ University of South Africa, Florida Science Campus, Florida 1710, South Africa; \\ coadebo@yahoo.com (C.O.O.); Mambabb@unisa.ac.za (B.B.M.) \\ 2 College of Agriculture and Environmental Sciences, Department of Environmental Sciences, \\ University of South Africa, Florida Science Campus, Florida 1710, South Africa; \\ ramganesh.presidency@gmail.com \\ * Correspondence: msagatam@unisa.ac.za; Tel.: +27-636-895-964
}

Received: 26 August 2019; Accepted: 9 October 2019; Published: 29 October 2019

\begin{abstract}
Next-generation sequencing provides new insights into the diversity and structure of bacterial communities, as well as the fate of pathogens in wastewater treatment systems. In this study, the bacterial community structure and the presence of pathogenic bacteria in three wastewater treatment plants across Gauteng province in South Africa were studied. The physicochemical results indicated that the quality of wastewater varies considerably from one plant to the others. Proteobacteria, Actinobacteria, Firmicutes, and Chloroflexi were the dominant phyla across the three wastewater treatment plants, while Alphaproteobacteria, Actinobacteria, Bacilli, and Clostridia were the dominant classes. The dominant bacterial functions were highly associated with carbohydrate, energy, and amino acid metabolism. In addition, potential pathogenic bacterial members identified from the influent/effluent samples included Roseomonas, Bacillus, Pseudomonas, Clostridium, Mycobacterium, Methylobacterium, and Aeromonas. The results of linear discriminant analysis (LDA) effect size analysis also confirmed that these bacterial pathogens were significantly abundant in the wastewater treatment systems. Further, the results of this study highlighted that the presence of bacterial pathogens in treated effluent pose a potential contamination risk, transmitted through soil, agriculture, water, or sediments. There is thus a need for continuous monitoring of potential pathogens in wastewater treatment plants (WWTPs) in order to minimize public health risk.
\end{abstract}

Keywords: high-throughput sequencing; bacteria; biodiversity; pathogens; wastewater treatment plant

\section{Introduction}

Waterborne infections emanate from the transmission of pathogenic microorganisms (bacteria, viruses, protozoa) by both direct and indirect ingestion of polluted water [1-4]. Most water-borne pathogens are spread through the fecal-oral route, and find their way to wastewater treatment plants (WWTPs) through excreted feces in raw sewage from infected people or in drinking water, or by eating food exposed to contaminated water, which could lead to serious health complications [4-7]. In recent years, bacterial pathogens have been recurrently identified in wastewater plants, based on the impression that WWTPs are a major reservoir for the growth of numerous pathogenic microbes $[2,6,8]$. Regardless of tremendous efforts by governments and water management facilities to improve and sustain the quality of water treatment systems, the occurrence of waterborne infections remains rampant 
worldwide [2,7]. Bacteria, which are abundant in WWTPs, play significant roles, such as breaking down organic matter, being a source of nutrients, and facilitating energy flow and biogeochemical cycling as well as disease transmission [9-12]. Traditionally, the main treatment processes in WWTPs include primary, biological (secondary), and tertiary treatment [13]. Primary treatment is a preliminary stage which makes use of bar screens to remove large solid objects from water. It can also include the use of sedimentation basins to separate solid from liquid waste by means of natural gravity. The floating materials are removed while the remaining liquids are laid open for the secondary stage of treatment through the use of biological methods (either aerobic or anaerobic) to break down the organic waste matter. The organic matter in the waste are removed through the use of a bed of stones (trickling filter beds) or the activated sludge process. Finally, effluents from the secondary treatment tank are then disinfected with chlorine, which is assumed to kill all pathogenic organisms and reduce odor, before being discharged into distribution channels and receiving water bodies. There has been a significant effort by water management authorities to adopt new techniques in treatment plants such as UV and membrane treatment technology, mechanical (ultrafiltration, reverse osmosis, nano-filtration), ultrasonic (ozonation), biological (active filters and enzymes), adsorption (activated carbon), and combinations of these processes to eliminate and partially remove microbes in wastewater [12-19]. Despite all these approaches, the existence of pathogenic microbes in raw and treated wastewater is still considered a potential hazard and health risk to the public $[6,12,14]$. At present, most WWTPs assess the quality of water based on biological indicators, such as the total coliforms and fecal coliforms [20], as well as physical and chemical indicators [13,21]. However, these assessment techniques do not directly classify the variety of the mixed bacterial populations present in WWTP systems.

Several molecular methods have been reported for the identification of bacterial species in environmental samples. There is, however, another challenge with regard to the species identification of microbes, in that a widespread selection of these environmental bacterial species cannot be cultured [22-24]. Over the years, molecular technologies such as polymerase chain reaction (PCR) [4,25-28], quantitative real-time PCR (qPCR) [4,28-30], microarray [4,31], and other techniques have been widely used to target microbial species in environmental samples [8,30]. All of these molecular techniques have both strengths and weaknesses, but these approaches are always delegated to specifically target the identification of a pre-selected group of microbes or virulence genes $[4,25,31,32]$. The main limitation of these technologies is that they can only specifically detect certain pathogens, and cannot provide comprehensive insight into the potential pathogens in the environment.

Current approaches in microbial detection (such as next-generation sequencing) have made it possible to extract DNA directly from environmental samples and sequences for identification, diversification, diagnostic, clinical, and monitoring purposes [33-39]. Recently, high-throughput next-generation sequencing methods applied to the 16S rRNA gene have produced complete descriptions of bacterial communities in various environments, due to the increased number of sequence reads that can be obtained and analyzed. A number of investigations have been performed into the microbial diversity and pathogenic indication of environmental genomes in WWTPs by sequencing of the 16S rRNA gene amplicon using different high-throughput techniques $[2,7,9,11,40,41]$. In this study, we investigated the abundance and diversity of the bacterial communities in influent and effluent wastewater samples from three WWTPs in South Africa, using a targeted amplicon-based sequencing approach. The study evaluated the potential biomarkers and abundance of bacterial communities that were removed after treatment processes to identify pathogens (including those not conventionally checked during quality assessment). 


\section{Materials and Methods}

\subsection{Sample Collection and Field Measurements}

Wastewater samples were obtained from three different treatment plants in Pretoria, Krugersdorp near Johannesburg city. Daspoort wastewater treatment works (S $25^{\circ} 44^{\prime} 063^{\prime \prime}$ E $028^{\circ} 10^{\prime} 688^{\prime \prime}$ ), is located on the southern bank of the Apies River, northwest of the central business district in Pretoria, and it flows into dams and reservoirs from which it is withdrawn back to WWTPs; these flows will be referred to as DI for (influent) and DE (effluent). This plant is designed to treat a capacity of 60 million liters (60 megalitre per day) of wastewater. Samples were also collected from the Percy Stewart (PS; PSI: influent; PSE: effluent) (S 26 51'18.4" E $\left.27^{\circ} 52^{\prime} 57.2^{\prime \prime}\right)$ wastewater treatment plants located in Krugersdorp. The effluent from the plant is discharged into the Bloubankspruit River which connects with the Crocodile River and the surrounding Hartbeespoort Dam. The final samples were from Flip Human (FH; FHI: influent; FHE: effluent) (S 26 $01^{\prime} 25.8^{\prime \prime}$ and E $\left.28^{\circ} 17^{\prime} 10.0^{\prime \prime}\right)$; its effluents are discharged into the neighboring Mooi River which flows to the Vaal Dam. The FH and PS treatment plants have an average daily flow capacity of 32 megalitre per day. All the treatment plants receive their waste mainly from households, industries, and hospitals in Pretoria, Krugersdorp in Johannesburg. The treatment processes in the three plants are quite similar but have different capacities. These comprise a coarse screen, fine screen, and a grit removal chamber for the removal of larger solids. The screened wastewater is then channeled into the primary sedimentation tank and a separate sludge digestion in rectangular tanks for the decomposition of waste, clarification, and then chlorination. All the studied plants make use of bio-filtration and biological nutrient removal (BNR) for the activated sludge system. The plants make use of bioreactors containing living material to capture and biologically degrade the organic matter. On the sludge side, a dissolved air flotation (DAF) thickening process is done to remove the suspended solids; dewatering of the sludge is accomplished using solar drying beds.

\subsection{Physicochemical Analysis of Water Samples}

From each sampling site (DE, DI, PSE, PSI, FHE, FHI), 2 L of raw (influent) and treated (effluent) wastewater samples from three different wastewater treatment plants were collected in triplicate in sterilized polypropylene bottles to prevent contamination and deterioration. The collected wastewater samples were preserved in ice-boxes and transported to the laboratory for further processing within $24 \mathrm{~h}$. About $500 \mathrm{~mL}$ of each sample was stabilized with $5 \mathrm{~mL}$ nitric acid for heavy metal analysis, and the analysis was performed in an inductively coupled optical emission spectrometer (ICP-OES, Perkin Elmer, Waltham, MA, USA). The other half of the sample was filtered using $0.45 \mu \mathrm{m}$ acrodisc ${ }^{\circledR}$ syringe filters (PALL life sciences, NY, USA). Anions were determined using ion chromatography (chloride, fluoride, nitrite, bromide, nitrate, phosphate, and sulfate), while the dissolved organic carbon (DOC) in the samples was determined using the total organic carbon analyzer. For each sampling point, selected physicochemical parameters such as temperature, $\mathrm{pH}$, dissolved oxygen, total dissolved solid (TDS), conductivity, and salinity were measured using the onsite multi-probe (YSI ${ }^{\mathrm{TM}} 6$ series, Sonde Marion, Germany) at the sampling site after collection.

\subsection{Nucleic Acid Extraction and 16S-rRNA-Based Amplicon Sequencing}

Prior to extraction, wastewater samples for molecular analysis were homogenized and filtered through a Whatman filter paper \#114 (Sigma-Aldrich, USA) to remove big and coarse particles. The filtrate samples were then passed through a $0.20 \mu \mathrm{m}$ Supor ${ }^{\circledR}$ membrane filter (PALL Life Sciences, NY, USA) using a peristaltic pump to concentrate the microbial cells. Total genomic DNA was extracted from the concentrated samples using the Soil/Fecal DNA Extraction Kit ${ }^{\mathrm{TM}}$ (Zymo Research Corporation, USA) according to the manufacturer's protocol. Total DNA was eluted and then quantified using a Qubit 3.0 Fluorometer (Life Technologies, Thermo Fisher Scientific, Waltham, MA, USA).

The extracted DNA was amplified with a set of primers targeting the hypervariable V1-V3 regions. The primers used were 27F (5'-AGAGTTTGA TCMTGGC-3') and 518R 
(5'-GTATTACCGCGGCTGCTGG-3'), as described by Sibanda et al. [38]. The PCR amplification reactions contained $25 \mu \mathrm{L}$ of one Taq $2 X$ Master Mix, $22 \mu \mathrm{L}$ of Nuclease-free water, and $1.5 \mu \mathrm{L}$ of both forward and reverse primers at a concentration of $0.2 \mu \mathrm{mol} / \mathrm{L}$ with a $2 \mu \mathrm{L}$ of extracted DNA (50-100 ng/ $\mu \mathrm{L}$ ) to make up a volume of $50 \mu \mathrm{L}$. The PCR conditions were set at $95{ }^{\circ} \mathrm{C}$ for $10 \mathrm{~min}$ for the initial denaturation, followed by 32 cycles of denaturation at $95^{\circ} \mathrm{C}$ for $30 \mathrm{~s}$, annealing at $55^{\circ} \mathrm{C}$ for $30 \mathrm{~s}$ and extension at $72{ }^{\circ} \mathrm{C}$ for $1 \mathrm{~min}$, and a final extension at $72{ }^{\circ} \mathrm{C}$ for $10 \mathrm{~min}$, followed by cooling to $4{ }^{\circ} \mathrm{C}$. All purified PCR products were then sequenced by paired-end sequencing chemistry, along with their multiplex sample identifiers on the Illumina MiSeq Platform (Inqaba Biotechnology, Pretoria, South Africa).

\subsection{Data Processing and Bioinformatics Analysis}

The quality control and filtering of the datasets were performed using MOTHUR pipeline version 1.40.0 [42]. The sequences were quality trimmed and paired-end joined using fastq-join to convert the overlapping paired-end reads into longer fragment sequences [43]. This was done to remove sequences with average quality scores of $8 \mathrm{nt}$, ambiguous bases, or $>2$ mismatches to primer sequences. The UCHIME algorithm was used to eliminate chimeric sequences using default parameters [44]. The non-chimeric (490 nt) sequence reads were aligned against the SILVA 16S rRNA gene reference database (version 128) with a confidence threshold of $80 \%[45,46]$. The assignment of operational taxonomic units (OTUs) was performed at $97 \%$ for species identification using the furthest neighbor algorithm. Evaluation of the observable characteristic bacteria from each WWTP was achieved through the METAGENassist online software [47]. The highest OTUs at genus level were used to generate a phylogenetic heat map to visualize the dominant taxonomy for each WWTP sample and determine dissimilarity between samples' bacterial communities. Statistical analysis-including one-way ANOVA and Turkey's multiple range tests-were calculated to compare the mean values of the tested parameters for all the different sampling sites. Community diversity indices were calculated based on the OTUs obtained from the influent and effluent samples using nonparametric diversity indices. Chao1, the abundance-base coverage estimator (ACE), Shannon index (H), Simpson index $(D)$, and Good's coverage index were calculated at a distance of 0.03 using PAST (Paleontological statistics) [48]. To identify the potential biomarkers with significant differences between influent and effluent samples, the linear discriminant analysis (LDA) effect size (LEfSe) method was used [49]. Likewise, PICRUSt (phylogenetic investigation of communities by reconstruction of unobserved states) analysis was used to predict the functional abilities of identified bacterial communities in the wastewater samples using the KEGG (Kyoto Encyclopedia of Genes and Genomes) orthologues and pathway [49]. Breifly, the dominant OTU gene sequences, which represented the most abundant genes in the sample were mapped against the Greengenes database, using 97\% confidence intervals to predict the presence of any functional gene in the sample [50]. The Ribosomal Database Project (RDP) classifier, using a method described previously by Wang et al. [51], was employed to identify possible pathogenic bacterial genera within the treatment plants.

\section{Results}

\subsection{Physicochemical Profiles of the Wastewater Samples}

The selected physical and chemical characteristics of the wastewater samples (DI, DE, FHI, FHE, PSI, and PSE) are presented in Table 1. The temperature of the sampling points ranged from 15.6 to $21.2{ }^{\circ} \mathrm{C}$, with an average temperature of $15.65^{\circ} \mathrm{C}$. Other physicochemical profiling parameters such as electrical conductivity (COND), salinity (SAL), DOC, dissolved oxygen (DO), and major anions noticeably varied among the wastewater samples. Greater variation of COND was observed in the water samples, with the values recorded ranging from influent $\left(685.5-902 \mu \mathrm{Scm}^{-1}\right)$ and effluent (506-1016 $\mu \mathrm{Scm}^{-1}$ ). The total dissolved solid (TDS) measured in the influent samples varied from 341 to $513.3 \mathrm{mg} / \mathrm{L}$, and from $253-508 \mathrm{mg} / \mathrm{L}$ in the effluent wastewater samples. The DOC, DO, salinity, 
and anions values varied among the influent and effluent samples. Statistically, the levels of $\mathrm{pH}, \mathrm{DO}$, DOC, TDS, SAL, COND, $\mathrm{Cl}^{-}, \mathrm{F}^{-}, \mathrm{SO}_{4}{ }^{2-}$, and $\mathrm{PO}_{4}{ }^{3-}$ were significantly higher $(p<0.05)$ in the studied influents of the WWTPs (Table 1). Furthermore, there were significant variations $(p<0.05)$ between the abovementioned parameters, except for $\mathrm{F}^{-}$and $\mathrm{DO}$, which were significantly lower $(p>0.05)$ in the effluent wastewater samples. Heavy metal concentrations in the wastewater samples were unequally distributed across the treatment plants (Figure 1). Samples PSI and PSE exhibited higher levels of $\mathrm{Ca}, \mathrm{Cu}, \mathrm{Fe}, \mathrm{Mn}, \mathrm{Ni}$, and $\mathrm{Zn}$; the DI and DE samples had higher concentrations of Fe, Mo, and $\mathrm{Mg}$; and the FHI and FHE samples revealed high concentrations of Co only in both the influent and effluent samples.

Table 1. Physicochemical properties of influent and effluent water samples observed from three wastewater treatment plants (WWTPs). (Mean $\pm \mathrm{SD}, n=3$ ).

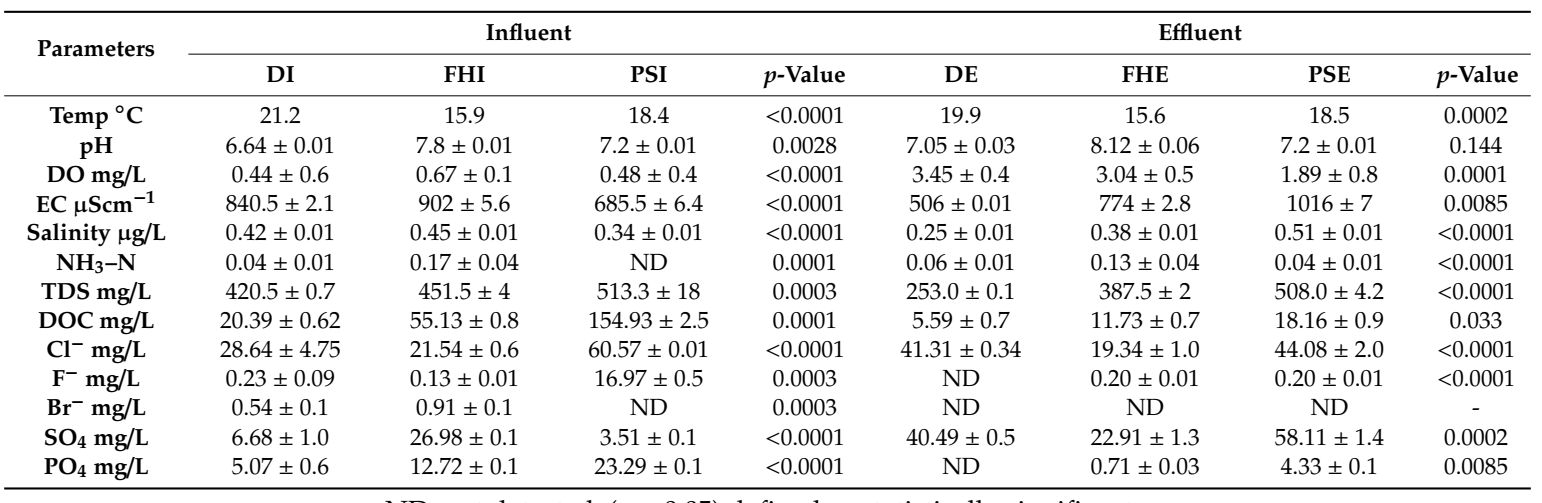

ND: not detected, $(p<0.05)$ defined as statistically significant.

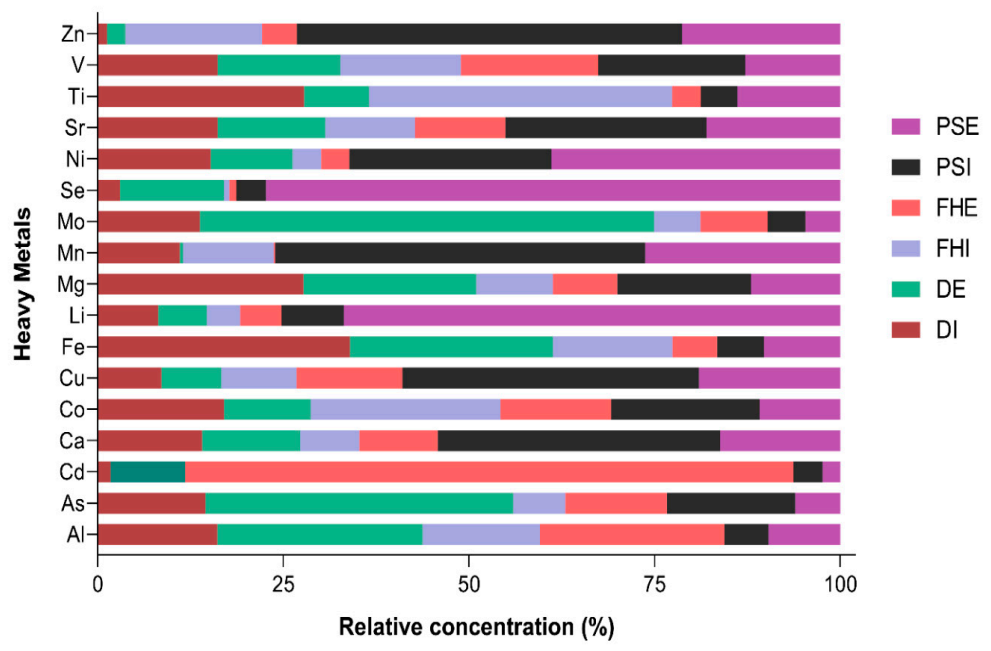

Figure 1. Heavy metal concentration levels (ppm) from the three WWTPs.

\subsection{Diversity Analysis for Bacterial Communities at the WWTPS}

Bacterial diversity was analyzed based on the 16S rRNA amplicon sequence analysis, resulting in a total of 395,529 reads across the six samples, distributed as follows: 42,069 reads for sample DE, 33,958 for sample DI, 81,220 for sample FHI, 62,939 for sample FHE, 75,331 for sample PSI, and 100,012 reads for sample PSE. After OTU picking, we found a total of 1506 OTUs based on a 0.97 threshold across all samples. The microbial diversity indices were calculated, encompassing community richness (ACE, Chao1) and community diversity (Shannon and Simpson indices). The lowest OTUs were observed in sample FHE, while the highest OTUs were found in sample DI. Each sample had more than $99 \%$ the coverage, indicating that the depth of the sequence was sufficient. According to the OTU numbers, the sample from DI (519) had the richest diversity, followed closely by the PSE (351) and FHI (229) 
samples, whereas the samples from FHE (104), PSI (144), and DE (159) displayed considerably less richness. As is shown in Table 2, the values of the Ace, Chao, and Shannon indices demonstrated that the DI samples had the highest microbial diversity, while FHE had the lowest.

Table 2. Summary for the bacterial richness and diversity of microbial communities for the WWTPs.

\begin{tabular}{ccccccc}
\hline Parameters & DI & DE & FHI & FHE & PSI & PSE \\
\hline Quality reads & 25,287 & 23,066 & 32,176 & 32,469 & 36,742 & 46,924 \\
Average read length & 518 & 491 & 471 & 469 & 471 & 473 \\
OTUs & 519 & 159 & 229 & 104 & 144 & 351 \\
Good's coverage \% & 99.90 & 99.40 & 99.90 & 99.90 & 100 & 99.90 \\
ACE & 659.6 & 179.8 & 257.5 & 116.5 & 150.1 & 369.2 \\
Chao1 & 620.7 & 170 & 240.2 & 110.1 & 146.2 & 357.3 \\
Shannon_H & 1.304 & 1.524 & 1.523 & 1.04 & 1.198 & 1.883 \\
Simpson_1-D & 0.663 & 0.347 & 0.484 & 0.568 & 0.51 & 0.383 \\
\hline
\end{tabular}

\subsection{Taxonomic Composition of the WWTPs' Microbial Communities}

The relative abundances of bacterial groups in the different influent and effluent samples were analyzed at the phylum, class, and genus levels. Overall, a total of 17 bacterial phyla, 36 classes, 62 orders, 101 families, and 299 genera were identified from the six samples. The bacterial community structures and the relative abundance at the phylum and class levels, based on the dominant groups, are displayed in Figures $2 \mathrm{a}$ and $2 \mathrm{~b}$ respectively. As indicated in Figure $2 \mathrm{a}$, at phylum level, the overall wastewater sequence reads were classified into three dominant phyla (relative abundance $\geq 1 \%$ in at least one sequence library), those being Proteobacteria, Firmicutes, and Actinobacteria. Samples FHE, FHI, PSE, PSI, and DE had the highest abundance of Proteobacteria (51.5\%), while sample DI had the lowest abundance (11.4\%). The influent sample DI had the highest abundance of Firmicutes $(82.9 \%)$, DE had $43.9 \%$, while PSI contained the most Actinobacteria (16.5\%). Bacteroidetes was only dominant in DI (6\%), while Chloroflexi represented about 3.5\% in PSI. At the class level, the dominant classes at the six wastewater samples were Alphaproteobacteria, Actinobacteria, Bacilli, and Clostridia (Figure 2b). Alphaproteobacteria were dominant in the majority of wastewater samples, including FHE, FHI, PSE, DE, and PSI, while in samples DI and DE, Bacilli was the dominant group. Other notable bacterial classes were Gammaproteobacteria, Flavobacteria, Bacteroidia, Firmicutes, Deltaproteobacteria, and Betaproteobacteria, which each contributed more than $1 \%$ to the total bacterial community in at least one sample.

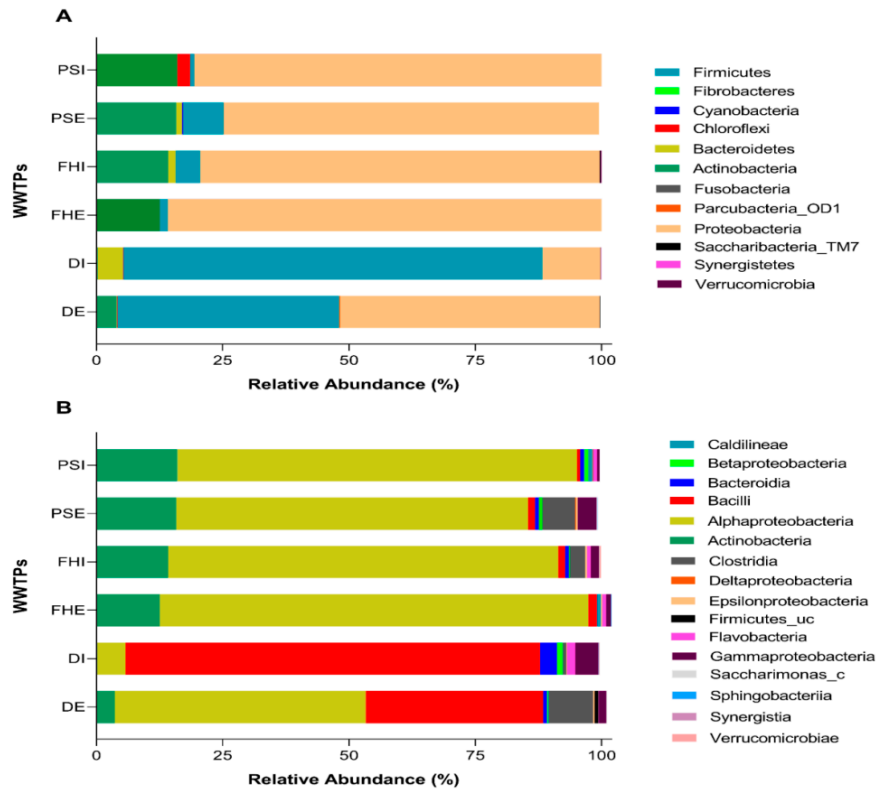

Figure 2. Bar charts showing (a) taxonomic distributions of dominant bacterial phyla and (b) taxonomic distributions of dominant bacterial classes for the six wastewater samples based on sequence data. 
At the genus level, 299 genera were acquired from all samples, with the top 60 being shared by all six samples; these accounted for about $60-88 \%$ of the classified sequences. The top 20 genera from the influent and effluent at the three WWTPs are shown in Figure 3. In total, more than $90 \%$ of the bacterial sequences from the samples were classified to the genus level. Among the 299 assigned genera, 14 were shared by all six samples; the influent and effluent samples were dominated by the genera Bacillus, Sphingobium, Roseomonas, Propionibacterium, SMB53, Acinetobacter, Methylobacterium, Clostridium, Pseudomonas, Paenibacillus, Enhydrobacter, Prevotella, Streptococcus, Staphylococcus, Hafnia, and Microbacterium. Rare genera were only observed in one or two samples, accounting for $1 \%$ of the total classified sequences in all six samples.

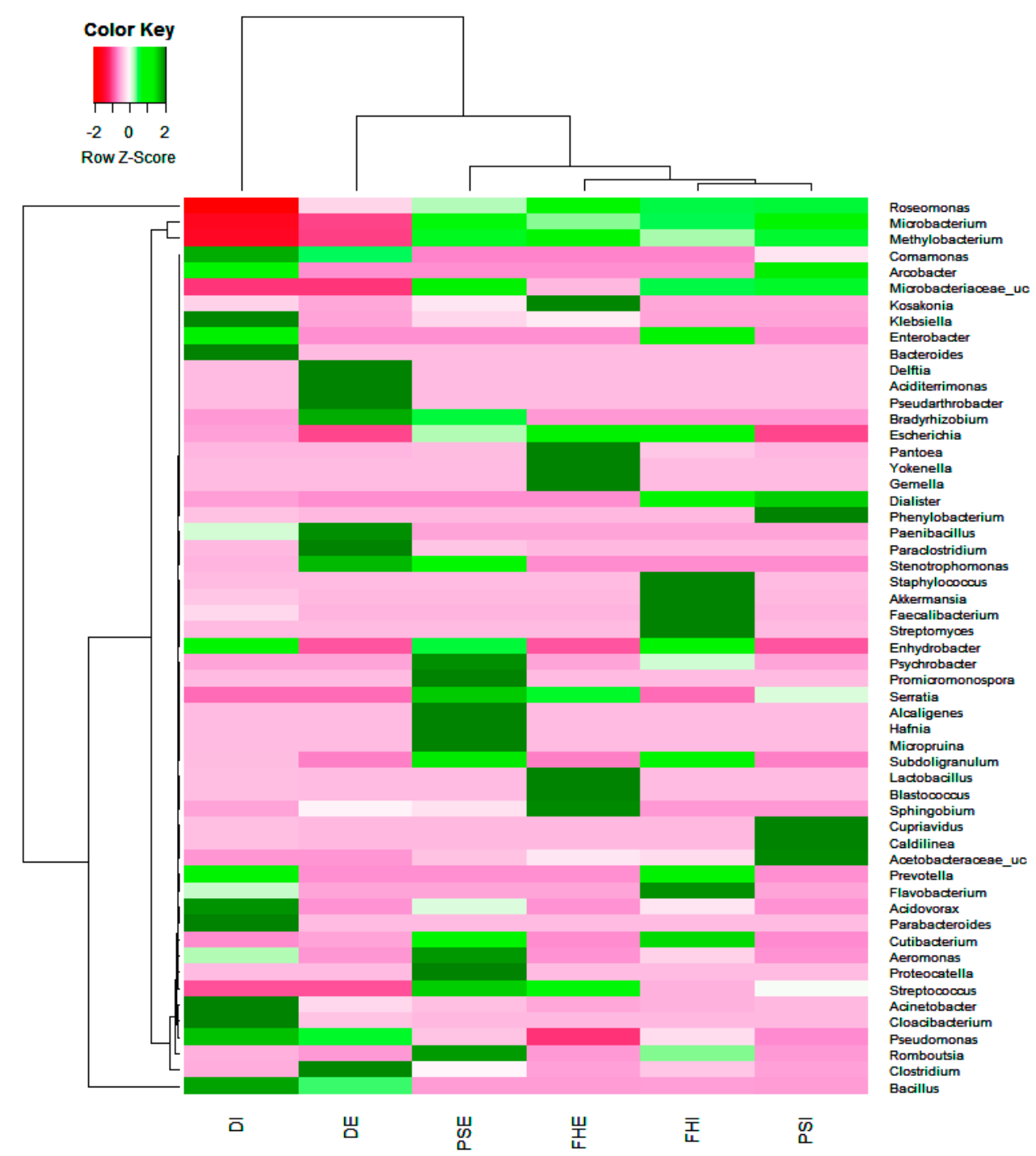

Figure 3. Heat map showing top 20 genera in the influent and effluent samples. The 20 dominant genera in each sample were selected and compared with their abundances (percentages) in other samples. The color intensity (log scale) in each panel shows the percentage of a genus in a sample, referring to a key.

A canonical correspondence analysis (CCA) bi-plot was used to illustrate the possible ecological relationships between microbial community and physicochemical variables within the WWTPs (Figure 4). CCA Axis 1 explained 91.15\% of the variance, while Axis 2 explained $6.28 \%$ of the variance in the bacteria-environmental parameters relationship. In essence, the length of the arrow is proportional to the rate of change, so a longer arrow indicates a larger change in environmental 
variable. The CCA plot revealed strong relationships between the bacterial communities and measured physical and chemical water quality variables. Results of CCA revealed that the samples DI and DE were significantly different from other samples. In samples DI and DE, the distribution of the classes Gammaproteobacteria, Betaproteobacteria, Bacteroidia, and Bacilli was influenced by a combination of heavy metals such as $\mathrm{Mg}, \mathrm{Fe}, \mathrm{Br}, \mathrm{As}$, and Mo. The samples from the other treatment plants (PSE, PSI, FHE and FHI) exhibited high amounts of $\mathrm{PO}_{4}, \mathrm{NH}_{3}, \mathrm{SO}_{4}, \mathrm{DO}, \mathrm{DOC}$ and metals (Ca, $\mathrm{Mg}, \mathrm{Zn}, \mathrm{Cl}, \mathrm{Ni}$ ); this significantly influenced the bacterial classes Epsilonproteobacteria, Alphaproteobacteria, Actinobacteria and Sphingobacteria. Members of Flavobacterium, Saccharimonas, and Clostridium did not show considerable impact from any of the physicochemical parameters observed in the wastewater treatment plants.

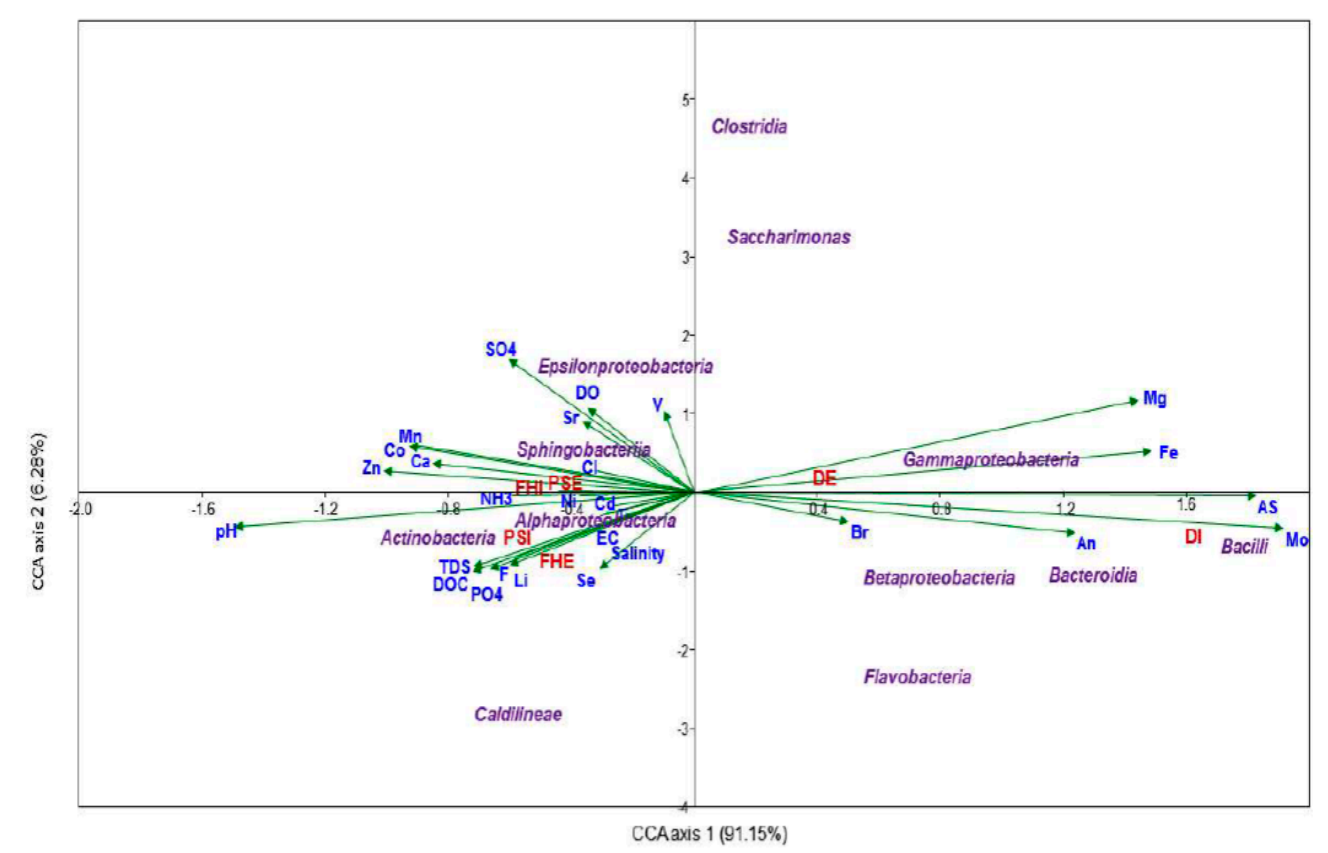

Figure 4. Canonical correspondence analysis (CCA) ordination plot shows the effect of physicochemical parameters on bacterial community structures (classes) in three different WWTPs.

\subsection{Significant Difference and Functions of Bacterial Communities in Influent and Effluent Samples}

To determine the classified bacterial taxa with significant abundance differences between the influent and effluent samples, the researchers performed biomarker analysis using linear discriminant analysis (LDA) effect size (LEfSe) analysis, as described by Segata and Huttenhower [49]. Differential features were identified at the OTU level (relative abundance $>1 \%$ ). The nonparametric factorial Kruskal-Wallis rank sum test was used to detect taxonomies with significant differential abundances, while the LDA score was used to estimate the effect size of each differentially abundant trait, according to a method proposed by Zhang et al. [52]. LEfSe was able to compare the estimated phylotypes and identify the most differentially abundant taxa between the influent and effluent samples. As shown in Figure 5a significant differential abundances occurred between the collected influent and effluent samples. A cladogram for order, class, and genus level abundance is shown in Figure $5 \mathrm{~b}$. Comparison between effluent and influent samples identified 17 major genera: Pseudomonas, Flavobacterium, Propionibacterium, Acinetobacter, and Enhydrobacter were mainly enriched in the influent samples, while the genera Roseomonas, Methylobacterium, Clostridium, Sphingobium, Microbacterium, and Bacillus were significantly enriched within effluent samples, with LEfSe scores of 5.84, 4.97, and 4.32 respectively. 


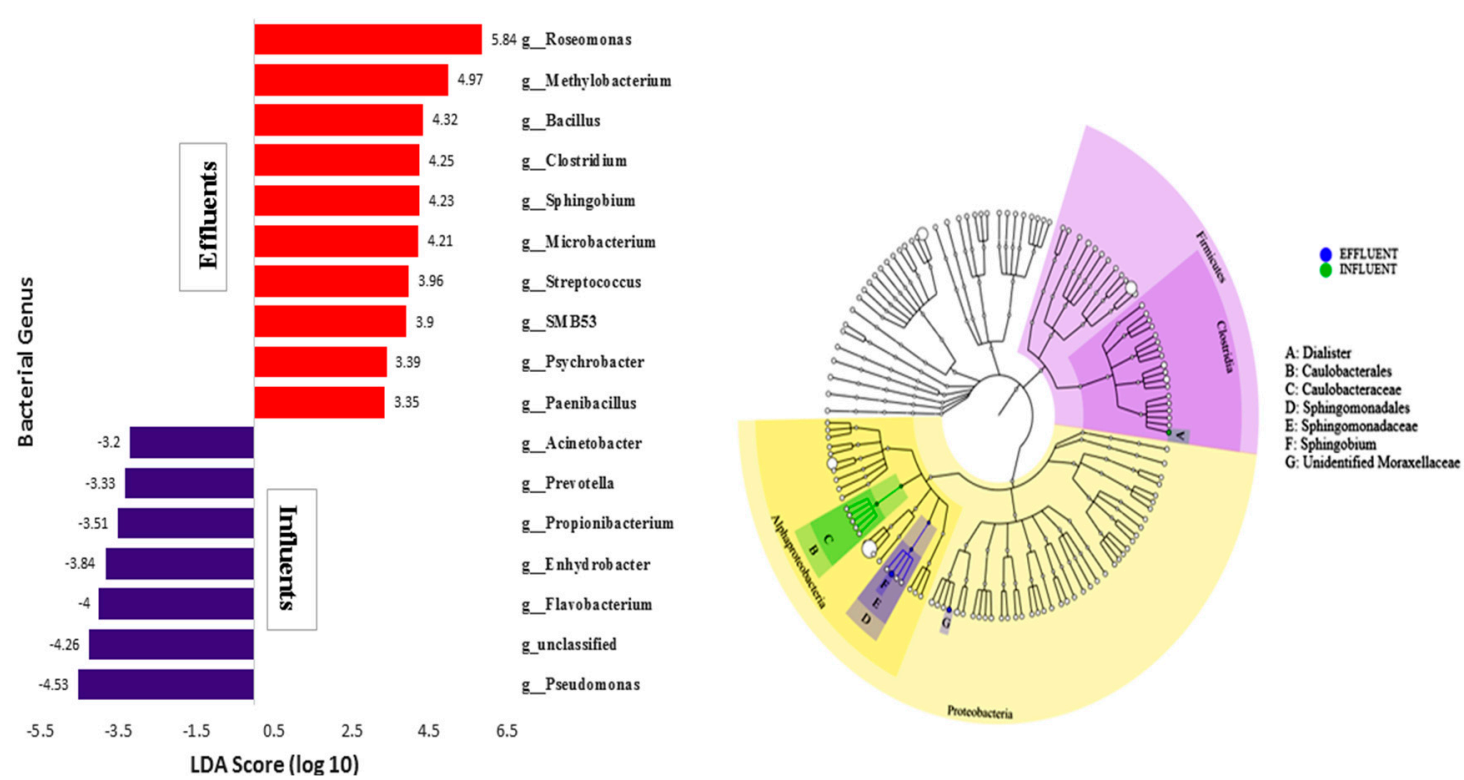

Figure 5. (a) Linear discriminant analysis (LDA) effect size (LEfSe) analysis showed differentially abundant genera as biomarkers determined using the Kruskal-Wallis test $(p<0.05)$, with LDA scores $>3.5$. (b) Cladogram representation of the differentially abundant orders, families, and genera. The root of the cladogram denotes the domain Bacteria, and the size of each node represents its relative abundance.

Prediction of the metabolic functions from the 16S rRNA gene amplicon sequencing of the three different wastewater plants was achieved using PICRUSt analysis. The predictive functional profiles of the bacterial communities of the six wastewater samples are shown in Figure 6. The most abundant and prevailing classification was the metabolic pathway, which included carbohydrate, energy, and amino acid metabolism. The genes most associated with amino acid metabolic pathways were pyruvate metabolism, purine metabolism, histidine metabolism, alanine aspartate and glutamate metabolism, $\mathrm{D}$ glutamine and $\mathrm{D}$ glutamate metabolism, and arginine and proline acid metabolism. The results indicated that carbohydrate metabolism serves as a major energy source for other cellular processes. This also aligns with the fact that a major proportion of the WWTP relates mainly to the degradation of organic pollutants. Besides the metabolic pathways, genes responsible for genetic information processing were identified, which included ribosome biogenesis, transcription, and translation factors. Other important identified functional interactions included ABC (ATP-binding cassette) transporters, ion-coupled transporters, and DNA repair and recombination proteins (Figure 6). 

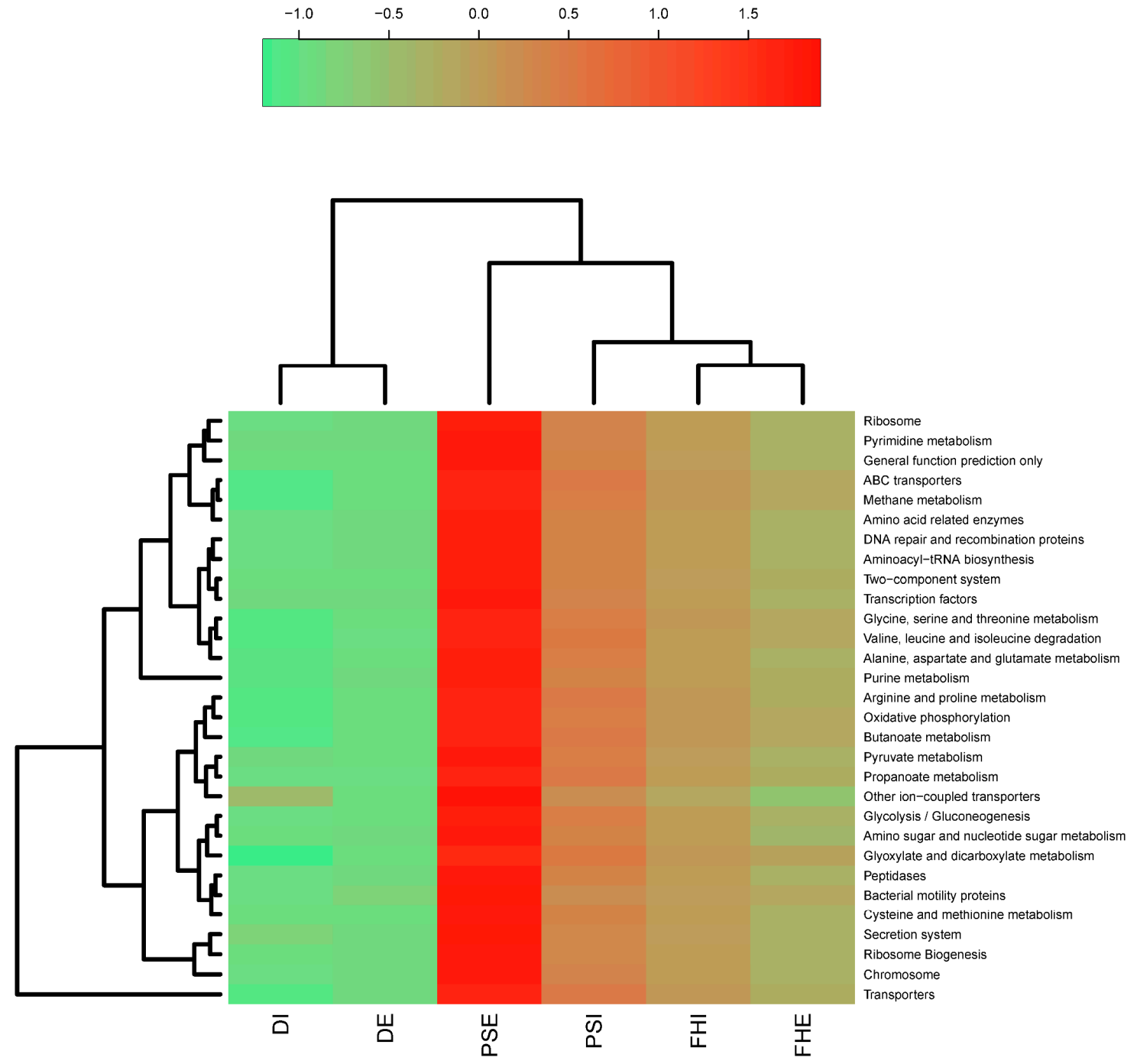

Figure 6. Heat map showing functional relative abundance in the WWTPs, predicted using PICRUSt (Phylogenetic investigation of communities by reconstruction of unobserved states) analysis.

\subsection{Detection of Potential Pathogenic Bacterial Members}

To investigate the presence of possible pathogens from the WWTP samples, the RDP classifier was used to identify pathogenic bacteria at the genus level. All the sequences identified as potentially pathogenic species were aligned using the local BLASTN tool; the read was identified as a potential pathogenic bacterium if it had an identity over $97 \%$ with its best BLAST hit. Most of the pathogenic bacterial 16S-rRNA-encoding DNA sequences were identified from the major phyla of Proteobacteria and Firmicutes. The results indicated that the pathogens in the WWTPs were relatively associated with 26 genera in the influent and effluent samples (Figure 7). At the genus level, the relative number of sequences apportioned to known pathogens was 10,863 (47.09\%) for DI; 20,543 (81.23\%) for DE; 24,018 (74\%) for FHE; 21,925 (68.14\%) for FHI; 2,817 (59.92\%) for PSE; and 25,459 (69.29\%) for PSI. The nine dominant genera Roseomonas, Pseudomonas, Bacillus, Clostridium, Faecalibacterum, Methylobacterium, Micobacterim, Mycobacterium, Prevotella, and Aeromonas were found to be dominant pathogens in all three WWTPs investigated. Among the genera identified, Roseomonas had the highest abundance in each wastewater sample, accounting for about $45 \%$ of all pathogenic sequences. Other genera, such as Yersinia, Legionella, Burkholderia, Chryseobacterium, Treponema, Synergistaceae, and Escherichia were also found to be over $1.35 \%$ in all samples, even after treatment. 


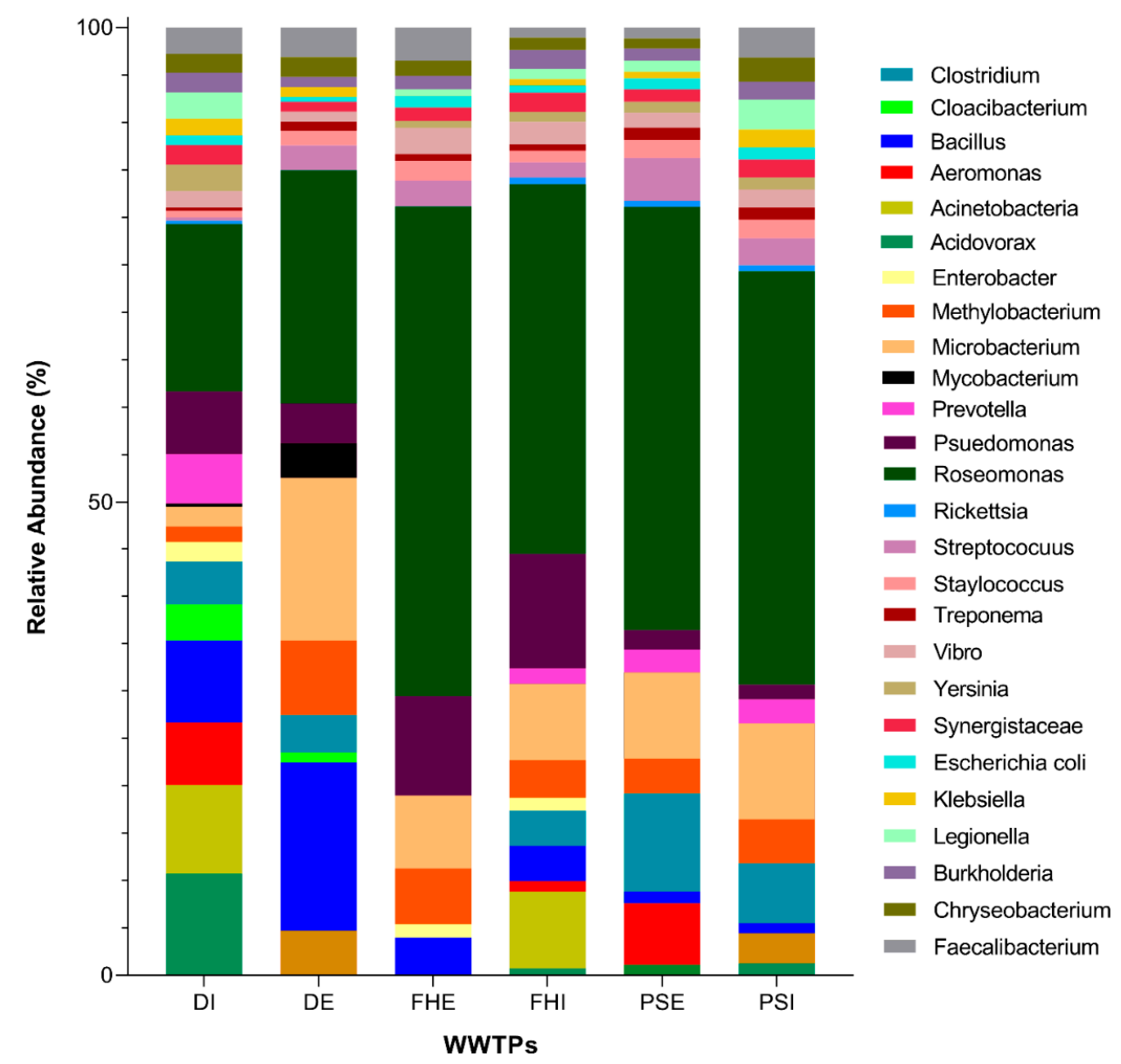

Figure 7. Potential pathogenic bacterial diversity and relative abundance at genus level at the WWTPs.

\section{Discussion}

WWTPs play a significant role in the overall health of the ecosystem; however, diverse types of pollutants are being deposited into them on a day-to-day basis. The $\mathrm{pH}$ of a wastewater system is an important indicator of the quality of the water and the degree of pollution in the area. In this study, the $\mathrm{pH}$ of the influent wastewater samples varied between each plant, indicating that the wastewater samples were neutral to slightly alkaline, which seems to support the bacterial growth and activities required for WWTPs. Furthermore, the range of $\mathrm{pH}$ values of the treatment plants observed in this study was within the suggested limits determined by the South African Department of Water Affairs and Forestry in the National Water Act, 36 of 1998, the World Health Organization, and data reported elsewhere [53-56]. With respect to conductivity, high COND values were observed in all samples, which could be attributed to the presence of suspended impurities and dissolved ions in the water samples [57]. The concentration of heavy metals in the samples varied from one plant to the next, indicating the high presence of urbanization and industrial activities within the CBD environs [58-60]. Overall, the study indicated that heavy metals were unequally distributed across the treatment plants. The PSI and PSE samples revealed higher levels of $\mathrm{Ca}, \mathrm{Cu}, \mathrm{Mn}, \mathrm{Fe}, \mathrm{Ni}$, and $\mathrm{Zn}$. On the other hand, samples DI and DE had higher concentrations of Fe, Mo, and Mg, while the FHI and FHE samples revealed high concentrations of Co only, in both the influent and effluent samples. The detection of $\mathrm{Zn}$, $\mathrm{Ni}, \mathrm{Fe}$, and other metals could have been the result of discharges from mine tailings, the extraction of metal ores, and erosion processes within the geographical location. Strengthening the monitoring and control of heavy metals at WWTPs can play a substantial role in improving environmental quality and reducing environmental risks associated with heavy metal pollution in water samples. 
The current study investigated the bacterial diversity at three WWTPs by analyzing the OTUs, Chao1, and Shannon indices at cut-off levels of $97 \%$. The results showed a slight difference in biodiversity among the influent and effluent samples. For example, the library derived from sample DI had the greatest number of OTUs (519), followed by samples PSE (351) and FHI (229), while sample FHE (104) had the smallest. Chao1 numbers were considerably higher than OTU numbers, which suggests that more OTUs may exist in these bacterial communities. However, no significant difference was observed in the Good's coverage value of all samples (>99\%), which suggests that the observed sequences could function as a sound representation of the bacterial communities present in the six wastewater samples [61]. To assess the within-sample complexity of individual microbial populations, the Shannon-Weaver index $(H)$ and evenness were calculated. The values of $H$ ranged from 1.04 to 1.883 across the six wastewater samples, indicating that sample PSE (1.883) had the highest bacterial diversity and was highly species-rich. The OTUs and ACE observed in this study were much lower than those reported in previous studies [61,62], which found an average of 700 OTUs and 900 ACEs per sample identified.

Proteobacteria was the predominant phylum, constituting between 11 and $85 \%$ of all detected OTUs within the influent and effluent samples, which is consistent with the results from previous bacterial community studies in WWTPs $[8,10,62,63]$. Firmicutes, Bacteriodetes, Actinobacteria, and Chloroflexi were the subdominant groups, comprising $0.8-82.9 \%, 0.1-5 \%, 3.9-16.1 \%$, and $0.1-2.5 \%$ of detections, respectively, within the six studied wastewater samples-which is consistent with previous studies $[7,9,62]$. In addition, a few low-abundance phyla accounted for more than $1 \%$ in at least one sample, such as Verrucomicrobia (0.2-1.3\%), Synergistetes (0.1-1.8\%), and Saccharibacteria_TM7 $(0.03-1.4 \%)$.

Within the Proteobacterial phylum, Alphaproteobacteria was the most abundant class, with FHE having the highest abundance of $85 \%$, and DI having the lowest abundance $(6 \%)$ across the wastewater samples. The studied WWTPs mainly deal with mixed wastes, domestic and industrial, and Alphaproteobacteria are known to be associated with bulking in industrial WWTPs [61]. A large population of Alphaproteobacteria has been detected in the WWTPs reported on in some others studies $[61,63]$. Thus, it can be established that Alphaproteobacteria is one of the prevailing bacterial species found in wastewater systems. Other prominent classes included Bacilli, with the highest abundance in DI (82\%), Actinobacteria (2.8-10.0\%), Clostridia (0.1-8.7\%), and Gammaproteobacteria $(0.5-5 \%)$. Flavobacteria had the lowest abundance in the wastewater samples, with values from $0.3-1.6 \%$. The Proteobacterial members are the largest and most diverse in the Bacterial domain; they are mostly Gram-negative bacteria, which are of importance to human health, as well as having great metabolic diversity.

The dominant genera belonged to nine bacterial phyla, namely Actinobacteria, Spirochaetae, Firmicutes, Bacteroidetes, Chloroflexi, Verrucomicrobia, Acidobacteria, Acidovorax, and $\alpha, \beta$, $\gamma$ Proteobacteria. The most abundant genera were Methylobacterium, Roseomonas, and Pseudomonas, at $0.5-6.5 \%$ in individual samples, while Microbacterium, Propionibacterium, Actinomycetes, Bifidobacteriales, and Thermoleopilia were reported at an abundance of $1.5-3.8 \%$ in individual samples. Clostridium and Bacillus varied from $1.2-2.5 \%$. The presence of these microbial species in WWTPs makes them potential targets for the bioremediation of some environmental pollutants $[64,65]$. Bioremediation involves the biological mechanisms of breaking down waste and pollutants into natural compounds and using them to restore the ecosystem to its original condition $[65,66]$. Studies have indicated that certain bacterial species can be used as bio-sorbents, which can help to degrade particular heavy metals [66-69], PCP [70], pesticides, poly-chlorinated biphenyl, and poly-aromatic hydrocarbons [67]. The additional use of microbe-based bio-sorbents for the elimination and recovery of toxic metals from industrial wastes can be an economical and active means of metal elimination. These results indicate that different WWTPs share a large proportion of their major bacterial populations, as these genera may play crucial roles in wastewater treatment regardless of geographic location. 
The results from the LDA effect size (LEfSe) analysis identified several taxa that were most characteristic of the differences between the influent and effluent samples. Among those prevalent in the influent samples were members of the Proteobacteria (Pseudomonas, Flavobacterium, and Enhydrobacter), as well as some unclassified genera. The effluent samples were more dominated by the genera Roseomonas, Methylobacterium, and Bacillus, while traces of Psychrobacter and Paenibacillus were also observed. Many taxa contributed significantly to differences in the influent and effluent samples, including the fecal indicator members of the families of Bacteroidetes, Enterobacteriaceae, Legionellaceae, and Arcobacter.

The putative metabolic functions of the microbial communities at different depths were predicted through the use of the PICRUSt pipeline, which indicated mainly fermentation, fatty acid oxidation, glycolysis/gluconeogenesis, and methanogenesis. The estimated microbial metabolism did not differ noticeably between the effluent and influent samples. However, the most important predicted metabolic pathway was membrane transport. Different categories of membrane transport (ABC transporters) were predicted in both influent and effluent bacterial communities. The most common pathways predicted for carbohydrate metabolism were pyruvate metabolism, glycolysis/gluconeogenesis, and glyoxylate and dicarboxylate metabolism. Pyruvate plays an important role in breaking down glucose in prokaryotic cells: carbohydrates are converted through gluconeogenesis to fatty acids through a reaction with acetyl-CoA, which is then used to provide further energy to the cells [69]. Glucose is predicted to be converted into pyruvate by some bacterial species communities, which can then be used for cellular respiration. Another predicted form of energy metabolism in the bacterial communities was methane metabolism; this indicates that there may have been some Proteobacterial species with the biochemical potential of using methane as their source of energy [70]. Verrucomicrobiae have also been suggested to degrade polysaccharides [71]. This prediction was based on the consumption of propanoate and butanoate by bacterial communities, which denotes the oxidation of fatty acid and fermentation activities [71]. Several amino acid synthesis pathways were predicted, of which the most prominent were the ribosome, cysteine, methionine, alanine, valine, leucine, aspartate, and glutamate syntheses, isoleucine degradation, glycine, serine, threonine metabolism, and amino-acid-related enzyme pathways. On the other hand, the CCA confirmed that the presence of some heavy metals and anions was more relevant with respect to microbial diversity in wastewater. However, further investigations are needed to reveal the temporal dynamic relationships between microbial community composition and physicochemical factors.

Water is one of the most important natural resources on the planet, and is also critical for the continuity of life. Wastewater, however, contains certain toxic chemicals, organic and inorganic substances, and pathogenic or disease-causing microorganisms [7]. An investigation into the existence of indicator microorganisms in drinking water is fundamental for determining microbiological quality and public health safety. WWTPs play a fundamental role in reducing the microbial load of human waste pollutants before the final effluent is discharged to households or ecosystems, or as bio-solids to be used in agricultural activities [72].

The timely and prompt recognition of potential pathogens in the environment is one of the most crucial steps in averting the outbreak of infectious diseases, as drinking-water-related illness outbreaks still occur worldwide [72]. The $16 \mathrm{~S}$ rRNA fingerprint has been used to identify those waterborne pathogens that have been indicated as priority pathogens by the $\mathrm{WHO}$, which pose a significant health threat $[53,55]$. The pathogenic bacterial sequences identified in this study included some of the most common very pathogenic bacteria, which could be used for microbial source tracking, including Roseomonas, Faecalibacterium, Bacillus, Aeromonas, Clostridium perfringens, Pseudomonas aeruginosa, and Escherichia coli in both the influent and effluent samples. The highest abundance of potential waterborne pathogens was observed in samples DE, DI, and FHI, accounting for about $75.5 \%$ of all the OTUs. The phylum Proteobacteria was the most dominant, accounting for $47.1-80 \%$ in all the pathogenic bacterial compositions. This aligns with previous studies that detected Proteobacterial pathogens at sewage plants due to fecal contamination [2,7]. These results also point to the existence of environmental 
bacteria, enteric bacteria, and bacterial species being transmitted through wastewater [63]. Among the bacterial pathogens identified, the genus Roseomonas was dominant in all the wastewater samples. Roseomonas species are now gradually being referred to as evolving opportunistic pathogens for their connection to human infectious diseases [73-75], and are mainly observed in patients with compromised immune systems $[74,75]$. The occurrence of this genus in higher percentages indicates that hospitals in the area probably accommodate patients with different health histories (HIV, psychiatric, and cancer), judging from the higher values obtained. Pseudomonas aeruginosa was also prevalent across the samples; this bacterium has the potential to grow on the surface of any plastic pipe within the plant, thereby leading to infections in people with low immunity, and it is also resistant to many antibiotic drugs [1]. Other pathogenic bacteria identified at the WWTPs were Chryseobacterium, Treponema, Staphylococuus, Streptococcus, Acinetobacteria, Aeromonas, and Faecalibacterium in both the influent and effluent samples-a finding which is consistent with previous studies into the presence of these genera and species at treatment plants [2,7]. From a public health perspective, the presence of Aeromonas genus in the effluent sample is cause for concern, as is it associated with human disease outbreaks [76,77]. These pathogens are known to adhere to the surfaces of pipes and could cause antibiotic resistance [78]. Escherichia coli (E. coli) can cause severe foodborne diseases which cause fever, vomiting, nausea, abdominal pain, and diarrhea [1,79]. Other evident pathogens at WWTPs that can cause diseases in the intestines, include Clostridium, Vibrio, Yersinia, and Faecalibacterium [2,7], an indication of fecal contamination. Additional pathogenic bacteria which were noticed in the effluent samples and are cause for alarm-especially in communities which take their water directly from the river-were Legionella, Bacillus, Klebsiella oxytoca, Burkholdria, and Mycobacteria. These species cause fever, cough, chest pain, headaches, shortness of breath, and diarrhea. Disinfection at treatment plants with the use of chlorine is an extensively used technology that has proven to be efficient in inactivating a great variety of pathogenic microorganisms. It was observed that even after the disinfection stage at the WWTPs, pathogens were still present in the final effluents that are being released to drinking water distribution channels and receiving water bodies in significant amounts. This might be as a result of the ability of the inactivated pathogens to re-grow again in the disinfected sample. It could also be as a result of low doses of chlorine, or, most likely, the water effluent was not disinfected before being released into the environment and other distribution channels. Therefore, wastewater treatment controls the pathogens, but does not guarantee the complete elimination of pathogenic bacteria.

\section{Conclusions}

In conclusion, the present study reported the bacterial community structure from three WWTPs using a high throughput next generation sequencing approach. Proteobacteria, Actinobacteria, and Firmicutes were the dominant phyla in all treatment plants, while Roseomonas and Enterobacter was the dominant pathogenic bacterial genera. The results of this study highlight that high throughput sequencing provides comprehensive and accurate insight into environmental bacterial pathogens that other conventional techniques fail to indicate during water quality assessment. Indeed, NGS-based detection approaches have the potential to be interpreted into actionable data for water quality managers. A limitation with the use of the partial $16 \mathrm{~S}$ rRNA approach is that there is a need for amplification step-this step could introduce some bias. This might affect the accurate picture of the bacterial communities actually present in the sample. In this study, the 16S rRNA approach was unable to identify new and divergent strains within the samples. There is still more work to be done in the development and application of metagenomic data analysis. Based on the observed findings, it is evident that pathogens can be dispersed via WWTPs and need to be removed, as they form the basis for environmental pathogen contamination and disease transmission. This poses a major threat to public health and water confidence levels, especially during water recycling and reuse in water-scarce situations in South Africa. 
Author Contributions: C.O.O., R.S., and T.A.M.M. conceived and designed the experiments; C.O.O., and R.S., performed the experiments; C.O.O., and R.S. analyzed the data; T.A.M.M. and B.B.M. contributed reagents/ materials/analysis tools; C.O.O. wrote the paper; R.S., T.A.M.M. and B.B.M. did the proofreading.

Acknowledgments: The authors are thankful to the University of South Africa (Unisa) for supporting this research. The financial assistance of the National Research Foundation (grant SFH170629246463) towards this research is hereby acknowledged. Authors also would like to thank CHPC, Pretoria for proving high computing facility for sequence analysis.

Conflicts of Interest: The authors of this work declare no conflict of interest.

\section{References}

1. Leclerc, H.; Schwartzbrod, L. Microbial Agents Associated with Waterborne Diseases. Crit. Rev. Microbiol. 2002, 28, 371-409. [CrossRef] [PubMed]

2. Cai, L.; Zhang, T. Detecting Human Bacterial Pathogens in Wastewater Treatment Plants by a High-Throughput Shotgun Sequencing Technique. Environ. Sci. Technol. 2013. [CrossRef] [PubMed]

3. Callejo, R.M.; Rodríguez-Naranjo, M.I.; Ubeda, C.; Hornedo-ortega, R.; Garcia-parrilla, M.C.; Troncoso, A.M. Reported Foodborne Outbreaks Due to Fresh Produce in the United States and European Union. Foodborne Pathog. Dis. 2015, 12, 32-38. [CrossRef] [PubMed]

4. Ramírez-Castillo, F.; Loera-Muro, A.; Jacques, M.; Garneau, P.; Avelar-González, F.; Harel, J.; Guerrero-Barrera, A. Waterborne Pathogens: Detection Methods and Challenges. Pathogens 2015, 4, 307-334. [CrossRef]

5. Fong, T.-T.; Lipp, E.K. Enteric viruses of humans and animals in aquatic environments: Health risks, detection, and potential water quality assessment tools. Microbiol. Mol. Biol. Rev. 2005, 69, 357-371. [CrossRef]

6. Okoh, A.I.; Odjadjare, E.E.; Igbinosa, E.O.; Osode, A.N. Wastewater treatment plants as a source of microbial pathogens in receiving watersheds. Afr. J. Biotechnol. 2007, 6, 2932-2944.

7. Huang, K.; Zhao, F.; Zhang, X.-X.; Ye, L.; Ren, H.; Zhang, T.; Mao, Y.; Ju, F.; Wang, Y.; Li, B. Free-living bacteria and potential bacterial pathogens in sewage treatment plants. Appl. Microbiol. Biotechnol. 2018, 102, 2455-2464. [CrossRef]

8. Cantalupo, P.G.; Calgua, B.; Zhao, G.; Hundesa, A.; Wier, A.D.; Katz, J.P.; Grabe, M.; Hendrix, R.W.; Girones, R.; Wang, D.; et al. Raw Sewage Harbors Diverse Viral Populations. MBio 2011. [CrossRef]

9. Wang, X.; Hu, M.; Xia, Y.; Wen, X.; Ding, K. Pyrosequencing analysis of bacterial diversity in 14 wastewater treatment systems in china. Appl. Environ. Microbiol. 2012, 78, 7042-7047. [CrossRef]

10. Jones, S.E.; Newton, R.J.; Mcmahon, K.D. Evidence for structuring of bacterial community composition by organic carbon source in temperate. Environ. Microbiol. 2009, 11, 2463-2472. [CrossRef]

11. Cydzik-Kwiatkowska, A.; Zielińska, M. Bacterial communities in full-scale wastewater treatment systems. World J. Microbiol. Biotechnol. 2016, 32, 1-8. [CrossRef] [PubMed]

12. Naidoo, S.; Olaniran, A.O. Treated wastewater effluent as a source of microbial pollution of surface water resources. Int. J. Environ. Res. Public Health 2013, 11, 249-270. [CrossRef] [PubMed]

13. Jover-Smet, M.; Martín-Pascual, J.; Trapote, A. Model of suspended solids removal in the primary sedimentation tanks for the treatment of urban wastewater. Water 2017, 9, 448. [CrossRef]

14. Lu, X.; Zhang, X.; Wang, Z.; Huang, K.; Wang, Y.; Liang, W. Bacterial Pathogens and Community Composition in Advanced Sewage Treatment Systems Revealed by Metagenomics Analysis Based on High-Throughput Sequencing. PLoS ONE 2015, 5, e0125549. [CrossRef] [PubMed]

15. Rajasulochana, P. Comparison on efficiency of various techniques in treatment of waste and sewage water A comprehensive review. Res.-Effic. Technol. 2016, 2, 175-184. [CrossRef]

16. Narmadha, D.; Mary Selvam Kavitha, V.J. Treatment of domestic wastewater using natural flocculants. Int. J. Life Sci. Biotechnol. Pharm. Res. 2012, 3, 206-213.

17. Rizzo, L.; Malato, S.; Antakyali, D.; Beretsou, V.G.; Dolic, M.B.; Gernjak, W.; Heath, E.; Ivancev-Tumbas, I.; Karaolia, P.; Lado Ribeiro, A.R.; et al. Consolidated vs new advanced treatment methods for the removal of contaminants of emerging concern from urban wastewater. Sci. Total Environ. 2018, 655, 986-1008. [CrossRef]

18. Sonune, A.; Ghate, R. Developments in wastewater treatment methods. Desalination 2004, 167, $55-63$. [CrossRef]

19. Collivignarelli, M.C.; Abbà, A.; Benigna, I.; Sorlini, S.; Torretta, V. Overview of the Main Disinfection Processes for Wastewater and Drinking Water Treatment Plants. Sustainability 2018, 10, 86. [CrossRef] 
20. Lucena, F.; Duran, A.E.; Morón, A.; Calderón, E.; Campos, C.; Gantzer, C.; Skraber, S.; Jofre, J. Reduction of bacterial indicators and bacteriophages infecting faecal bacteria in primary and secondary wastewater treatments. J. Appl. Microbiol. 2004, 97, 1069-1076. [CrossRef]

21. José Figueras, M.; Borrego, J.J. New perspectives in monitoring drinking water microbial quality. Int. J. Environ. Res. Public Health 2010, 7, 4179-4202. [CrossRef] [PubMed]

22. Gholizadeh, M.H.; Melesse, A.M.; Reddi, L. A comprehensive review on water quality parameters estimation using remote sensing techniques. Sensors 2016, 16, 1298. [CrossRef] [PubMed]

23. Vartoukian, S.R.; Palmer, R.M.; Wade, W.G. Strategies for culture of "unculturable" bacteria. FEMS Microbiol. Lett. 2010, 309, 1-7. [CrossRef] [PubMed]

24. Schmeisser, C.; Steele, H.; Streit, W.R. Metagenomics, biotechnology with non-culturable microbes. Appl. Microbiol. Biotechnol. 2007, 75, 955-962. [CrossRef] [PubMed]

25. Girones, R.; Ferrús, M.A.; Alonso, J.L.; Rodriguez-Manzano, J.; Calgua, B.; de Abreu Corrêa, A.; Hundesa, A.; Carratala, A.; Bofill-Mas, S. Molecular detection of pathogens in water - The pros and cons of molecular techniques. Water Res. 2010, 44, 4325-4339. [CrossRef] [PubMed]

26. Gugliandolo, C.; Lentini, V.; Spanò, A.; Maugeri, T.L. Conventional and molecular methods to detect bacterial pathogens in mussels. Lett. Appl. Microbiol. 2011, 52, 15-21. [CrossRef]

27. Botes, M.; De Kwaadsteniet, M.; Cloete, T.E. Application of quantitative PCR for the detection of microorganisms in water. Anal. Bioanal. Chem. 2013, 405, 91-108. [CrossRef]

28. Toze, S. PCR and the Detection of Microbial Pathogens in Water and Wastewater. Water Res. 1999, 33, 3545-3556. [CrossRef]

29. Ricchi, M.; Bertasio, C.; Boniotti, M.B.; Vicari, N.; Russo, S.; Tilola, M.; Bellotti, M.A.; Bertasi, B. Comparison among the quantification of bacterial pathogens by $\mathrm{qPCR}, \mathrm{dPCR}$, and cultural methods. Front. Microbiol. 2017, 8, 1-15. [CrossRef]

30. Järvinen, A.K.; Laakso, S.; Piiparinen, P.; Aittakorpi, A.; Lindfors, M.; Huopaniemi, L.; Piiparinen, H.; Mäki, M. Rapid identification of bacterial pathogens using a PCR- and microarray-based assay. BMC Microbiol. 2009, 9, 161.

31. Lee, D.-Y.; Lauder, H.; Cruwys, H.; Falletta, P.; Beaudette, L.A. Development and application of an oligonucleotide microarray and real-time quantitative PCR for detection of wastewater bacterial pathogens. Sci. Total Environ. 2008, 398, 203-211. [CrossRef] [PubMed]

32. Osunmakinde, C.O.; Selvarajan, R.; Sibanda, T.; Mamba, B.B.; Msagati, T.A.M. Overview of trends in the application of metagenomic techniques in the analysis of human enteric viral diversity in Africa's environmental regimes. Viruses 2018, 10, 429. [CrossRef] [PubMed]

33. Miller, R.R.; Montoya, V.; Gardy, J.L.; Patrick, D.M.; Tang, P. Metagenomics for pathogen detection in public health. Genome Med. 2013, 5, 81. [CrossRef] [PubMed]

34. Breitbart, M.; Hoare, A.; Nitti, A.; Siefert, J.; Haynes, M.; Dinsdale, E.; Edwards, R.; Souza, V.; Rohwer, F.; Hollander, D. Metagenomic and stable isotopic analyses of modern freshwater microbialites in Cuatro Ciénegas, Mexico. Environ. Microbiol. 2009, 11, 16-34. [CrossRef] [PubMed]

35. Thomas, T.; Gilbert, J.; Meyer, F. Metagenomics - a guide from sampling to data analysis. Microb. Inform. Exp. 2012, 2, 3. [CrossRef] [PubMed]

36. Sharpton, T.J. An introduction to the analysis of shotgun metagenomic data. Front. Plant. Sci. 2014, 5, 1-14. [CrossRef]

37. Ramganesh, S.; Timothy, S.; Memory, T. Thermophilic bacterial communities inhabiting the microbial mats of 'indifferent' and chalybeate (iron-rich) thermal springs: Diversity and biotechnological analysis. Microbiologyopen 2018, 7, 1-12.

38. Sibanda, T.; Selvarajan, R.; Msagati, T.; Venkatachalam, S.; Meddows-Taylor, S. Defunct gold mine tailings are natural reservoir for unique bacterial communities revealed by high-throughput sequencing analysis. Sci. Total Environ. 2019, 650, 2199-2209. [CrossRef]

39. Sibanda, T.; Selvarajan, R.; Tekere, M. Targeted $16 \mathrm{~S}$ rRNA amplicon analysis reveals the diversity of bacterial communities in carwash effluents. Int. Microbiol. 2018, 22, 181-189. [CrossRef]

40. Zhang, T.; Shao, M.F.; Ye, L. 454 Pyrosequencing reveals bacterial diversity of activated sludge from 14 sewage treatment plants. ISME J. 2012, 6, 1137-1147. [CrossRef] 
41. Ahmed, W.; Staley, C.; Sidhu, J.; Sadowsky, M.; Toze, S. Amplicon-based profiling of bacteria in raw and secondary treated wastewater from treatment plants across Australia. Appl. Microbiol. Biotechnol. 2017, 101, 1253-1266. [CrossRef] [PubMed]

42. Schloss, P.D.; Westcott, S.L.; Ryabin, T.; Hall, J.R.; Hartmann, M.; Hollister, E.B.; Lesniewski, R.A.; Oakley, B.B.; Parks, D.H.; Robinson, C.J.; et al. Introducing mothur: Open-source, platform-independent, community-supported software for describing and comparing microbial communities. Appl. Environ. Microbiol. 2009, 75, 7537-7541. [CrossRef] [PubMed]

43. Aronesty, E. Comparison of Sequencing Utility Programs. Open Bioinform. J. 2013, 7, 1-8. [CrossRef]

44. Edgar, R.C.; Haas, B.J.; Clemente, J.C.; Quince, C.; Knight, R. UCHIME improves sensitivity and speed of chimera detection. Bioinformatics 2011, 27, 2194-2200. [CrossRef]

45. Quast, C.; Pruesse, E.; Yilmaz, P.; Gerken, J.; Schweer, T.; Glo, F.O.; Yarza, P.; Peplies, J.; Glöckner, F.O. The SILVA ribosomal RNA gene database project: Improved data processing and web-based tools. Nucleic Acids Res. 2013, 41, 590-596. [CrossRef]

46. Pruesse, E.; Quast, C.; Knittel, K.; Fuchs, B.M.; Ludwig, W.; Peplies, J.; Glöckner, F.O. SILVA: A comprehensive online resource for quality checked and aligned ribosomal RNA sequence data compatible with ARB. Nucleic Acids Res. 2007, 35, 7188-7196. [CrossRef]

47. Arndt, D.; Xia, J.; Liu, Y.; Zhou, Y.; Guo, A.C.; Cruz, J.A.; Sinelnikov, I.; Budwill, K.; Nesbø, C.L.; Wishart, D.S. METAGENassist: A comprehensive web server for comparative metagenomics. Nucleic Acids Res. 2012, 40, 88-95. [CrossRef]

48. Hammer, Ø.; Harper, D.; Ryan, P.D. Paleontological statistics software package for education and data analysis. Palaeontol. Electron. 2001, 4, 9-18.

49. Segata, N.; Huttenhower, C. Toward an efficient method of identifying core genes for evolutionary and functional microbial phylogenies. PLoS ONE 2011. [CrossRef]

50. Langille, M.G.I.; Zaneveld, J.; Caporaso, J.G.; Mcdonald, D.; Knights, D.; Reyes, J.A.; Clemente, J.C.; Burkepile, D.E.; Thurber, R.L.V.; Knight, R.; et al. Analysis Predictive functional profiling of microbial communities using $16 \mathrm{~S}$ rRNA marker gene sequences. Nat. Biotechnol. 2013, 31, 814-821. [CrossRef]

51. Wang, Q.; Garrity, G.M.; Tiedje, J.M.; Cole, J.R. Native Bayesian classifier for rapid assignment of rRNA sequences into the new bacterial taxonomy. Appl. Environ. Microbiol. 2007, 73, 5261-5267. [CrossRef] [PubMed]

52. Zhang, C.; Li, S.; Yang, L.; Huang, P.; Li, W.; Wang, S.; Zhao, G.; Zhang, M.; Pang, X.; Yan, Z.; et al. Structural modulation of gut microbiota in life-long calorie-restricted mice. Nat. Commun. 2013, 4, 2163. [CrossRef] [PubMed]

53. Wang, X.; Xia, Y.; Wen, X.; Yang, Y.; Zhou, J. Microbial community functional structures in wastewater treatment plants as characterized by GeoChip. PLoS ONE 2014, 9, e93422. [CrossRef] [PubMed]

54. National Water Act 36 of 1998 Wastewater Limit Values Applicable to the Irrigation of Any Land or Property up to 50 Cubic Metres. Gov. Gaz. No. 19182 2013, Notice No., 17-18. Available online: https://cer.org.za/wp-content/uploads/2014/02/Revision-of-General-Authorisations-2013.pdf (accessed on 8 March 2018).

55. WHO Guidelines for Drinking-water Quality. Available online: https://www.who.int/water_sanitation_ health/dwq/GDWQ2004web.pdf (accessed on 8 May 2018).

56. Tanyol, M.; Demir, V. Correlations between some operation parameters and efficiency evaluation of domestic wastewater treatment plant in Tunceli (Turkey). Desalin. Water Treat. 2016, 57, 28115-28121. [CrossRef]

57. WHO Guidelines for Drinking-water Quality Second Addendum to Third Edition WHO Library Cataloguing-in-Publication Data. 2008, pp. 17-19. Available online: https://www.who.int/water_sanitation_ health/dwq/fulltext.pdf (accessed on 7 July 2018).

58. Ma, Y.; Egodawatta, P.; McGree, J.; Liu, A.; Goonetilleke, A. Human health risk assessment of heavy metals in urban stormwater. Sci. Total Environ. 2016, 557-558, 764-772. [CrossRef] [PubMed]

59. Duan, B.; Zhang, W.; Zheng, H.; Wu, C.; Zhang, Q.; Bu, Y. Comparison of health risk assessments of heavy metals and as in sewage sludge from wastewater treatment plants (WWTPs) for adults and children in the urban district of Taiyuan, China. Int. J. Environ. Res. Public Health 2017, 14, 1194. [CrossRef] [PubMed]

60. Feng, J.; Chen, X.; Jia, L.; Liu, Q.; Chen, X.; Han, D.; Cheng, J. Effluent concentration and removal efficiency of nine heavy metals in secondary treatment plants in Shanghai, China. Environ. Sci. Pollut. Res. 2018, 25, 17058-17065. [CrossRef] 
61. Xu, S.; Yao, J.; Ainiwaer, M.; Hong, Y.; Zhang, Y. Analysis of Bacterial Community Structure of Activated Sludge from Wastewater Treatment Plants in Winter. Biomed. Res. Int. 2018, 2018, 1-8. [CrossRef]

62. Numberger, D.; Ganzert, L.; Zoccarato, L.; Mühldorfer, K.; Sauer, S.; Grossart, H.-P.; Greenwood, A.D. Characterization of bacterial communities in wastewater with enhanced taxonomic resolution by full-length 16S rRNA sequencing. Sci. Rep. 2019, 9, 9673. [CrossRef]

63. Tian, H.; Liu, J.; Feng, T.; Li, H.; Wu, X.; Li, B. Assessing the performance and microbial structure of biofilms adhering on aerated membranes for domestic saline sewage treatment. RSC Adv. 2017, 7, 27198-27205. [CrossRef]

64. Naik, M.; Duraphe, M.D. Review paper on-Parameters affecting bioremediation. Int. J. Life Sci. 2012, 2, L77-L80.

65. Bernard, E.I.; Stanley, I.R.; Okoduwa, G.O.; Ebere, P.A.; Abraham, O.A.; Ibe, K.E. Toxicity and Bioremediation of Heavy Metals Contaminated Ecosystem from Tannery Wastewater: A Review. J. Toxicol. 2018, 2018, 2568038. [CrossRef] [PubMed]

66. Gupta, A.; Joia, J.; Sood, A.; Sood, R.; Sidhu, C.; Kaur, G. Microbes as Potential Tool for Remediation of Heavy Metals: A Review. J. Microb. Biochem. Technol. 2016, 8, 364-372. [CrossRef]

67. Malla, M.A.; Dubey, A.; Yadav, S.; Kumar, A.; Hashem, A.; Abd-Allah, E.F. Understanding and designing the strategies for the microbe-mediated remediation of environmental contaminants using omics approaches. Front. Microbiol. 2018, 9, 1132. [CrossRef]

68. Ojuederie, O.B.; Babalola, O.O. Microbial and plant-assisted bioremediation of heavy metal polluted environments: A review. Int. J. Environ. Res. Public Health 2017, 14, 1504. [CrossRef]

69. Kreth, J.; Lengeler, J.W.; Jahreis, K. Characterization of Pyruvate Uptake in Escherichia coli K-12. PLoS ONE 2013, 8, 6-12. [CrossRef]

70. Trotsenko, V.A.; Khmelenina, V.N. Aerobic methanotrophic bacteria of cold ecosystems. FEMS Microbiol. Ecol. 2015, 53, 15-26. [CrossRef]

71. Semrau, J.D.; Dispirito, A.A.; Yoon, S. Methanotrophs and copper. FEMS Microbiol. Rev. 2010, 34, 496-531. [CrossRef]

72. Pandey, P.K.; Kass, P.H.; Soupir, M.L.; Biswas, S.; Singh, V.P. Contamination of water resources by pathogenic bacteria. AMB Express 2014, 4, 1-16. [CrossRef]

73. Kim, Y.K.; Moon, J.S.; Song, K.E.; Lee, W.K. Two cases of bacteremia due to roseomonas mucosa. Ann. Lab. Med. 2016, 36, 367-370. [CrossRef]

74. Romano-Bertrand, S.; Bourdier, A.; Aujoulat, F.; Michon, A.L.; Masnou, A.; Parer, S.; Marchandin, H.; Jumas-Bilak, E. Skin microbiota is the main reservoir of Roseomonas mucosa, an emerging opportunistic pathogen so far assumed to be environmental. Clin. Microbiol. Infect. 2016, 22, 737.e1-737.e7. [CrossRef] [PubMed]

75. Diesendorf, N.; Köhler, S.; Geißdörfer, W.; Grobecker-Karl, T.; Karl, M.; Burkovski, A. Characterisation of Roseomonas mucosa isolated from the root canal of an infected tooth. BMC Res. Notes 2017, 1, 1-6. [CrossRef] [PubMed]

76. Igbinosa, I.H.; Igumbor, E.U.; Aghdasi, F.; Tom, M.; Okoh, A.I. Emerging Aeromonas species infections and their significance in public health. Sci. World, J. 2012, 2012, 1326. [CrossRef] [PubMed]

77. Jin, D.; Kong, X.; Cui, B.; Jin, S.; Xie, Y.; Wang, X.; Deng, Y. Bacterial communities and potential waterborne pathogens within the typical urban surface waters. Sci. Rep. 2018, 8, 1-9. [CrossRef] [PubMed]

78. Janda, J.M.; Abbott, S.L. The genus Aeromonas: Taxonomy, pathogenicity, and infection. Clin. Microbiol. Rev. 2010, 23, 35-73. [CrossRef]

79. Ibekwe, A.M.; Leddy, M.; Murinda, S.E. Potential human pathogenic bacteria in a mixed urban watershed as revealed by pyrosequencing. PLoS ONE 2013, 8, e79490. [CrossRef]

(C) 2019 by the authors. Licensee MDPI, Basel, Switzerland. This article is an open access article distributed under the terms and conditions of the Creative Commons Attribution (CC BY) license (http://creativecommons.org/licenses/by/4.0/). 